\title{
Experimental Study on Tortional Shear Behaviour of High Strength Steel Fiber Reinforced Concrete with Varying Volume Fraction
}

\author{
Bolagani. bhavani", Mr. Giridhar, Mr. Sundhara Kumar \\ Jntu kakinada
}

*Corresponding Author: Bolagani. bhavani, Jntu kakinada

\begin{abstract}
Behaviour of reinforced Concrete beams under pure torsion, torsional impact were studied experimentally using straight and crimpled fibers with varying volume fraction. Failures of the specimen, effects of the fiber content, twist behaviour and torsion strain behaviour are carried out. In the first set of investigations, seven types of specimens having dimensions of $500 \times 100 \times 100 \mathrm{~mm}$, with 0\%, 0.5\%, 1.0\% and $1.5 \%$ volume fraction of straight and crimpled steel fibers having aspect ratio 100, were used. During the investigations, cracking torque, ultimate torque, angle of twist and torsional stiffness were assessed.reinforcement with stirrups and torsion reinforcement with stirrups were used. During the investigations, cracking torque, ultimate torque, angle of twist and torsional stiffness were assessed. In the second set of investigations, six types of specimens having dimensions of $500 \times 100 \times 100 \mathrm{~mm}$, with and without $1.0 \%$ volume fraction of crimpled steel fibers, having aspect ratio 100 together with flexural reinforcement. In the tortion impact, seven types of specimens having dimensions of $500 \times 100 \times 100 \mathrm{~mm}$, with $0 \%, 0.5 \%, 1.0 \%$ and $1.5 \%$ volume fraction of straight and crimpled steel fibers having aspect ratio 100, were used. These specimens were to be tested under torsional impact and the energy required to produce cracking and ultimate torque compared. In this investigation, six types of

specimens, having dimensions of $500 \times 100 \times 100 \mathrm{~mm}$, with and without $1.0 \%$ volume fraction of crimpled steel fibers having aspect ratio 100, together with flexural reinforcement with stirrups and torsion reinforcement with stirrups were used. During the investigations, cracking torque, ultimate torque, angle of twist, and torsional stiffness were assessed.
\end{abstract}

\section{INTRODUCTION}

Till the 1960s the design engineers generally ignored torsion. It was assumed that torsion effects were minor and could be taken care of by the large safety factor used in flexural design. Torsion design began to arouse serious interest by the late 1950s because of three major stimuli. Firstly, ultimate strength design method was accepted as a replacement for the working stress design method. In the new ultimate strength design method, flexural analysis of reinforced concrete members was refined and safety factors were more accurately defined so that negligence of torsion effects was no longer acceptable. Secondly, the rapid advances in electronic computer application in structural analysis allowed engineers to consider many more design factors. Thirdly, in the post-world war II development, modern architectural concepts such as buildings, considered as three-dimensional structures rather than flat-plane objects, out of plane loading, curved beams, skew structures and irregular shapes were introduced. The new design often required structural members to resist large torsion moments. Post-Second world war design engineers neglected the effects of torsion but only considered bending, shear and axial forces. We may raise a question about the emphasis on analyzing torsion.

\section{Principles of Design for Combined Bending, Shear And Torsion by iS 456}

Bending shear and torsion are combined to an equivalent shear $\mathrm{V}_{\mathrm{e}}$. Similarly, the bending moment and torsional moment are combined to an equivalent bending moment $\mathrm{M}_{\mathrm{e}}$. The reinforced concrete section is then designed for $\mathrm{V}_{\mathrm{e}}$ and $\mathrm{M}_{\mathrm{e}}$.

\subsection{Calculation of Equivalent Shear and Design for Stirrups}

$V_{e}=V_{u} \frac{1.6 T_{u}}{B}$

where, 
$\mathrm{V}_{\mathrm{e}}$ is equivalent shear

$\mathrm{V}_{\mathrm{u}}$ is shear force

$\mathrm{T}_{\mathrm{u}}$ is design torsional moment

$\mathrm{b}$ is breadth of beam

The equivalent bending moment $\mathrm{M}_{\mathrm{t}}$ due to torsion $\mathrm{T}_{\mathrm{u}}$ is given by

$M_{t}=\frac{T_{u} 1 \frac{D}{b}}{1.7}$

$\mathrm{M}_{\mathrm{e}=} \mathrm{M}_{\mathrm{u}+} \mathrm{M}_{\mathrm{t}}$

Where

$\mathrm{T}_{\mathrm{u}}$ is design torsional moment

$\mathrm{M}_{\mathrm{u}}$ is design-bending moment

$\mathrm{D}$ is overall depth of the beam

$\mathrm{b}$ is breadth of the beam

$\mathrm{M}_{\mathrm{e}}$ is equivalent total bending moment

$\mathrm{M}_{\mathrm{t}}$ is equivalent bending moment due to torsion

\subsection{Design for Compression Steel}

If $\mathrm{M}_{\mathrm{t}}>\mathrm{M}_{\mathrm{e}}$, then there can be reversal of moment, and longitudinal steel has to be provided on the flexural compression face also, so that the beam can withstand the equivalent moment

$\mathrm{M}_{\mathrm{e} 2}=\mathrm{M}_{\mathrm{t}}-\mathrm{M}_{\mathrm{u}}$

\subsection{Category-1: Investigation on Steel Fiber Reinforced Concrete Beams under Pure Torsion}

In the first set of investigations, seven types of specimens having dimensions of $500 \times 100 \times 100 \mathrm{~mm}$, with $0 \%, 0.5 \%, 1.0 \%$ and $1.5 \%$ volume fraction of straight and crimpled steel fibers having aspect ratio 100, were used. During the investigations, cracking torque, ultimate torque, angle of twist and torsional stiffness were assessed.

\subsection{Category-2: Investigation on Steel Fiber Reinforced Concrete Beams under Torsional Impact}

In this investigation, seven types of specimens having dimensions of $500 \times 100 \times 100 \mathrm{~mm}$, with $0 \%$, $0.5 \%, 1.0 \%$ and $1.5 \%$ volume fraction of straight and crimpled steel fibers having aspect ratio 100, were used. These specimens were to be tested under torsional impact and the energy required producing cracking and ultimate torque compared.

\subsection{Category-3: Investigation on Steel Fiber Reinforced Concrete Beams under Cyclic Tortion}

In this investigation, six types of specimens, having dimensions of $500 \times 100 \times 100 \mathrm{~mm}$, with and without $1.0 \%$ volume fraction of crimpled steel fibers having aspect ratio 100 , together with flexural reinforcement with stirrups and torsion reinforcement with stirrups were used. During the investigations, cracking torque, ultimate torque, angle of twist, and torsional stiffness were assessed.

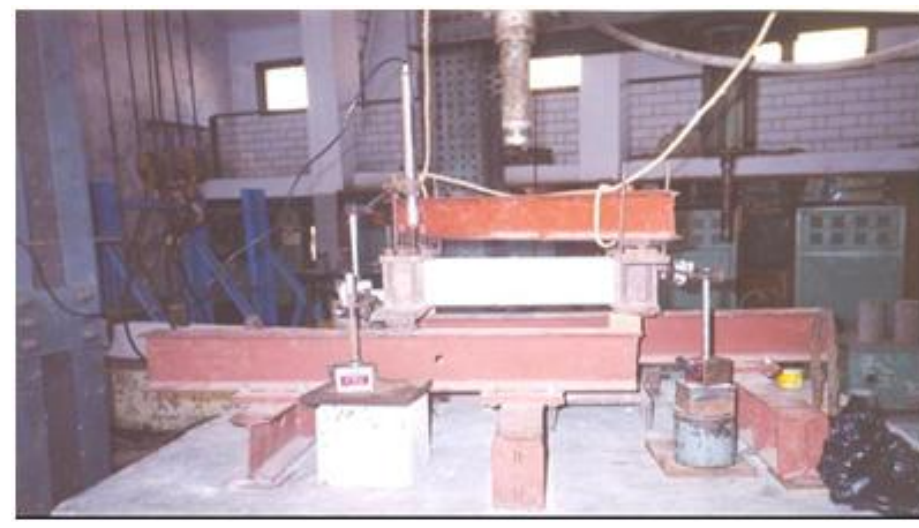

Loading arrangement

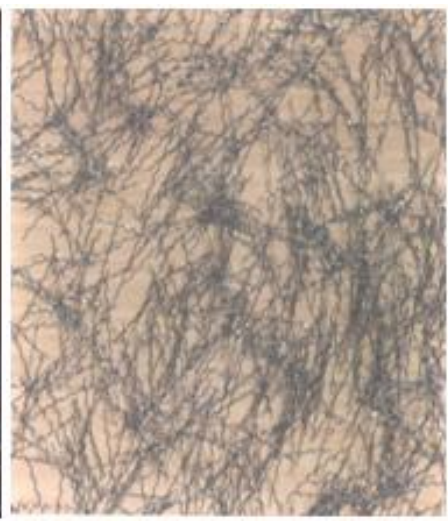

Crimbled fibers 
Experimental Study on Tortional Shear Behaviour of High Strength Steel Fiber Reinforced Concrete with Varying Volume Fraction

Table. Details of mix design

\begin{tabular}{|l|c|c|}
\hline Sl. No. & Properties & Values adopted \\
\hline 1 & Required cube strength (at 28 days) & Very good \\
\hline 2 & Degree of quality control & High \\
\hline 3 & Degree of workability & Ordinary Portland cement \\
\hline 4 & Type of cement & Natural river sand \\
\hline 5 & Type of sand & Crushed granite (Angular) \\
\hline 6 & Type of coarse aggregate & 2.15 \\
\hline 7 & Maximum size of coarse aggregate & 2.61 \\
\hline 8 & Specific gravity of cement & 0.45 \\
\hline 10 & Specific gravity of sand & $1: 1.36: 2.32$ \\
\hline 11 & Specific gravity of coarse aggregate & \\
\hline 12 & Water/cement ratio & Proportion of mix \\
\hline
\end{tabular}

\section{Details of steel fiber reinforced concrete}

\begin{tabular}{|c|c|c|c|c|c|c|}
\hline Sl. No. & $\begin{array}{c}\text { Concrete } \\
\text { strength } \\
\mathrm{N} / \mathrm{mm}^{2} \\
\end{array}$ & $\begin{array}{l}\text { Type of } \\
\text { fiber }\end{array}$ & $\begin{array}{l}\text { Volume } \\
\text { fraction } \\
\text { of fiber }\end{array}$ & $\begin{array}{c}\text { Dimension } \\
(\mathbf{l} \times \mathbf{b} \times \mathbf{d}) \\
\mathbf{M m}\end{array}$ & $\begin{array}{c}\text { Designation } \\
\text { of } \\
\text { specimen }\end{array}$ & $\begin{array}{c}\text { No. of } \\
\text { Specimen }\end{array}$ \\
\hline 1 & \multirow[t]{7}{*}{25} & \multirow[t]{4}{*}{ Straight } & $0 \%$ & \multirow[t]{7}{*}{$500 \times 100 \times 100$} & $\mathrm{~B} 1 \mathrm{~T}$ & 3 \\
\hline 2 & & & $0.5 \%$ & & $\mathrm{~B} 2 \mathrm{~T}$ & 3 \\
\hline 3 & & & $1.0 \%$ & & B3T & 3 \\
\hline 4 & & & $1.5 \%$ & & B4T & 3 \\
\hline 5 & & \multirow[t]{3}{*}{ Crimpled } & $0.5 \%$ & & B5T & 3 \\
\hline 6 & & & $1.0 \%$ & & B6T & 3 \\
\hline 7 & & & $1.5 \%$ & & $\mathrm{~B} 7 \mathrm{~T}$ & 3 \\
\hline \multicolumn{6}{|c|}{ Total no. of specimens } & 21 \\
\hline
\end{tabular}

Detailed experimental program for steel fiber reinforced concrete beams with reinforcement $(2000 \times 150$ x 230mm)

\begin{tabular}{|c|c|c|c|c|c|}
\hline $\begin{array}{l}\text { Sl. } \\
\text { No. }\end{array}$ & $\begin{array}{l}\text { Concrete } \\
\text { strength } \\
\mathrm{N} / \mathrm{mm}^{2}\end{array}$ & $\begin{array}{c}\text { Dimension } \\
(\mathbf{l} \times \mathbf{b} \times \mathbf{d}) \\
\mathbf{m m}\end{array}$ & Type of reinforcement & $\begin{array}{l}\text { Designation } \\
\text { of specimen }\end{array}$ & $\begin{array}{c}\text { No. of } \\
\text { Specimen }\end{array}$ \\
\hline 1 & \multirow[t]{6}{*}{25} & \multirow[t]{6}{*}{$200 \times 150 \times 230$} & $\begin{array}{c}\text { Flexural reinforcement } \\
\text { with shear } \\
\text { reinforcement }\end{array}$ & BL1T & 3 \\
\hline 2 & & & $\begin{array}{l}\text { Flexural reinforcement } \\
\text { with shear } \\
\text { reinforcement } \\
\text { and with } 1.0 \% \text { crimpled } \\
\text { fiber content }\end{array}$ & BL2T & 3 \\
\hline 3 & & & $\begin{array}{c}\text { Torsion reinforcement } \\
\text { with shear } \\
\text { reinforcement } \\
\end{array}$ & BL3T & 3 \\
\hline 4 & & & $\begin{array}{c}\text { Torsion reinforcement } \\
\text { with shear } \\
\text { reinforcement } \\
\text { and with } 1.0 \% \text { crimpled } \\
\text { fiber content }\end{array}$ & BL4T & 3 \\
\hline 5 & & & $\begin{array}{c}\text { Flexural reinforcement } \\
\text { with welded mesh as } \\
\text { shear reinforcement }\end{array}$ & BL5T & 3 \\
\hline 6 & & & $\begin{array}{c}\text { Flexural reinforcement } \\
\text { with welded mesh as } \\
\text { shear reinforcement and } \\
\text { with } 1.0 \% \text { crimpled } \\
\text { fiber } \\
\text { content }\end{array}$ & BL6T & 3 \\
\hline
\end{tabular}


Experimental Study on Tortional Shear Behaviour of High Strength Steel Fiber Reinforced Concrete with Varying Volume Fraction

\begin{tabular}{|c|c|c|c|c|}
\hline 7 & & $\begin{array}{c}\text { Torsion reinforcement } \\
\text { with welded mesh as } \\
\text { shear reinforcement }\end{array}$ & BL7T & 3 \\
\cline { 4 - 5 } & & $\begin{array}{c}\text { Torsion reinforcement } \\
\text { with welded mesh as } \\
\text { shear reinforcement and } \\
\text { with } 1.0 \% \text { crimpled } \\
\text { fiber content }\end{array}$ & BL8T & 3 \\
\hline \multicolumn{2}{|c|}{ Total no. of specimens } & \\
\hline
\end{tabular}
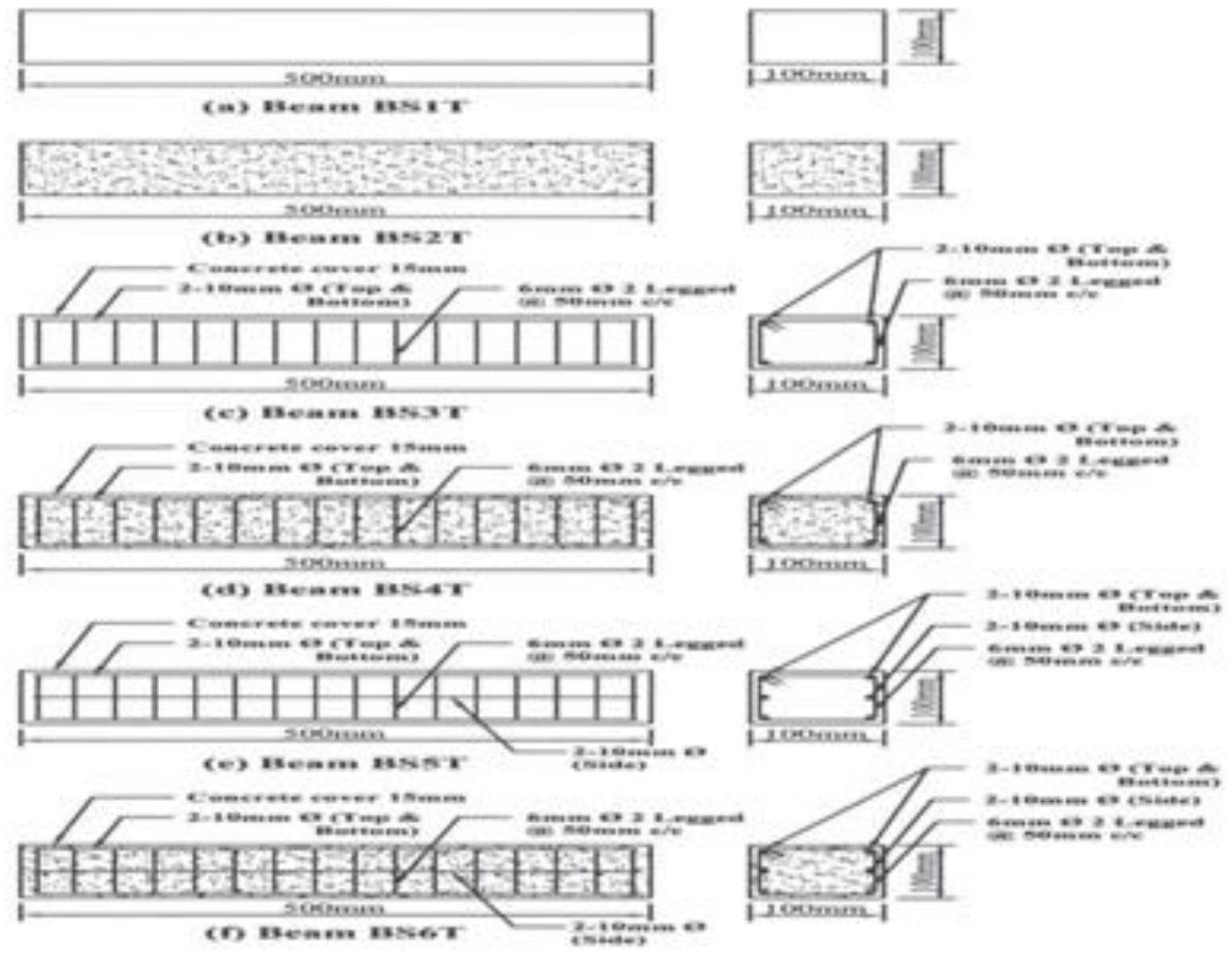

Detailment of reinforced concrete beam

Comparisons of cracking torque and ultimate torque

\begin{tabular}{|c|c|c|c|c|}
\hline Test Specimen & Type of fiber & $\begin{array}{c}\text { Volume fraction of } \\
\text { fiber }\end{array}$ & $\begin{array}{c}\text { Cracking Torque } \\
\times 10^{-3} \mathrm{kN} \cdot \mathrm{m}\end{array}$ & $\begin{array}{c}\text { Ultimate Torque } \\
\times 10^{-3} \mathrm{kN} . \mathrm{m}\end{array}$ \\
\hline B1T & \multirow[t]{4}{*}{ Straight } & $0 \%$ & 1059 & 1258 \\
\hline B2T & & $0.5 \%$ & 1192 & 1324 \\
\hline B3T & & $1.0 \%$ & 1258 & 1391 \\
\hline B4T & & $1.5 \%$ & 1324 & 1457 \\
\hline B5T & \multirow[t]{3}{*}{ Crimpled } & $0.5 \%$ & 1258 & 1391 \\
\hline B6T & & $1.0 \%$ & 1391 & 1523 \\
\hline B7T & & $1.5 \%$ & 1523 & 1655 \\
\hline
\end{tabular}

The torque at first crack of fiber reinforced concrete beam with $0.5 \%, 1.0 \%$ and $1.5 \%$ crimpled fiber content was found to be $19 \%, 31 \%$ and $44 \%$ more when compared with plain concrete beam. Similarly the torque at failure of fiber reinforced concrete beam with $0.5 \%, 1.0 \%$ and $1.5 \%$ crimpled fiber content was found to be $11 \%, 21 \%$ and $32 \%$ more when compared with plain concrete beam.

\subsection{Effect of Fiber Content}

The torque at first crack and failure showed a continuous increase with increase in fiber volume in both straight and crimpled fiber for the three-volume fraction as shown in Figure 4.5 and Figure 4.6. The increase in torque atcrack and failure was not appreciable in the case of straight fiber but, in the case of crimpled fiber, there was substantial increase in torque at both first crack and failure. 
Experimental Study on Tortional Shear Behaviour of High Strength Steel Fiber Reinforced Concrete with Varying Volume Fraction

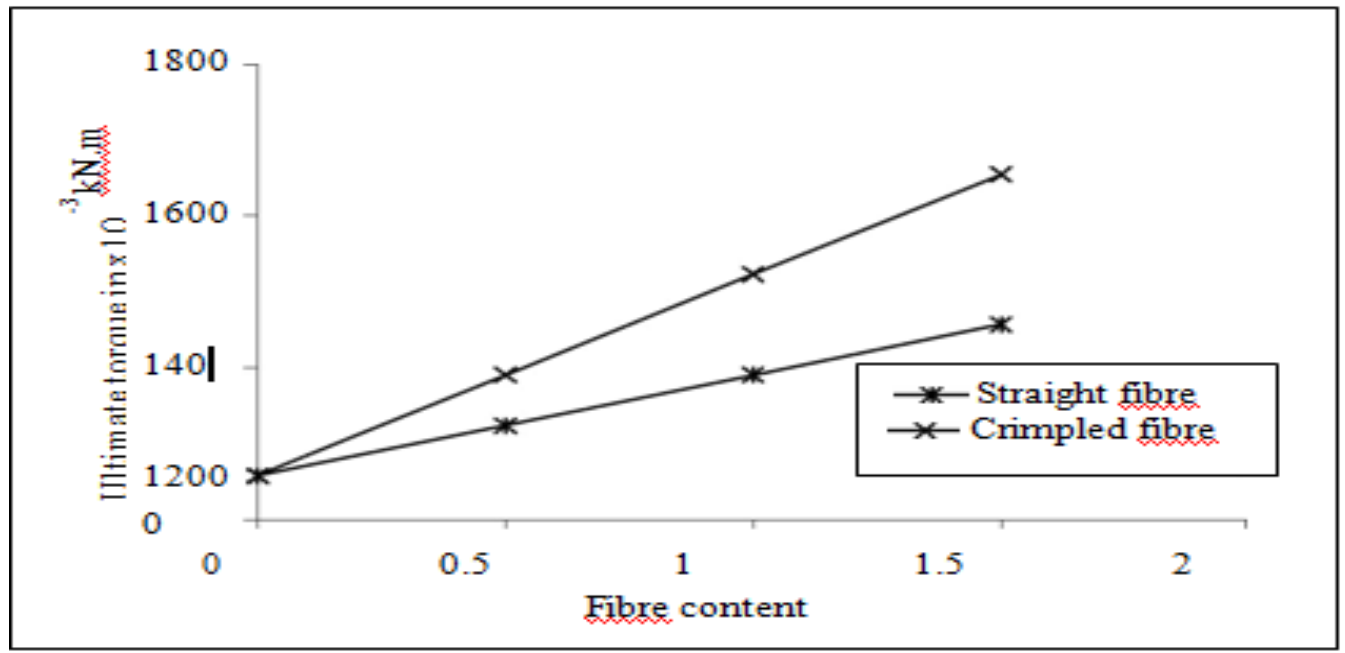

Torque versus angle of twist behavior without reinforcement

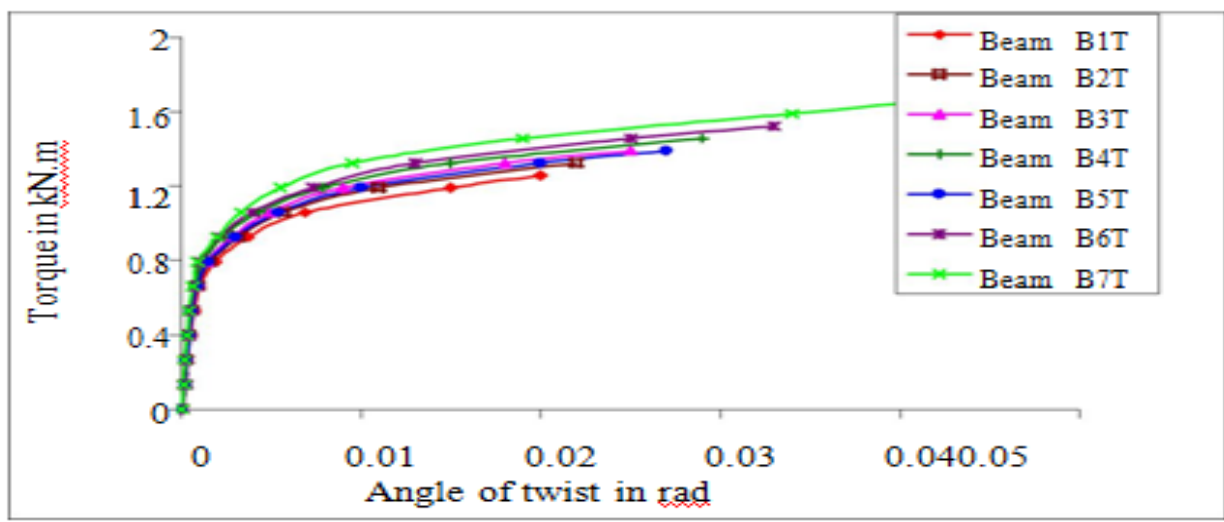

Relationship between torque and angle of twist

At higher loads appreciable magnitudes of twist were observed showing the ductility of the beams. The torque-twist curves of the beams are linear up to about $80 \%$ of their torsional strength after which they become non-linear

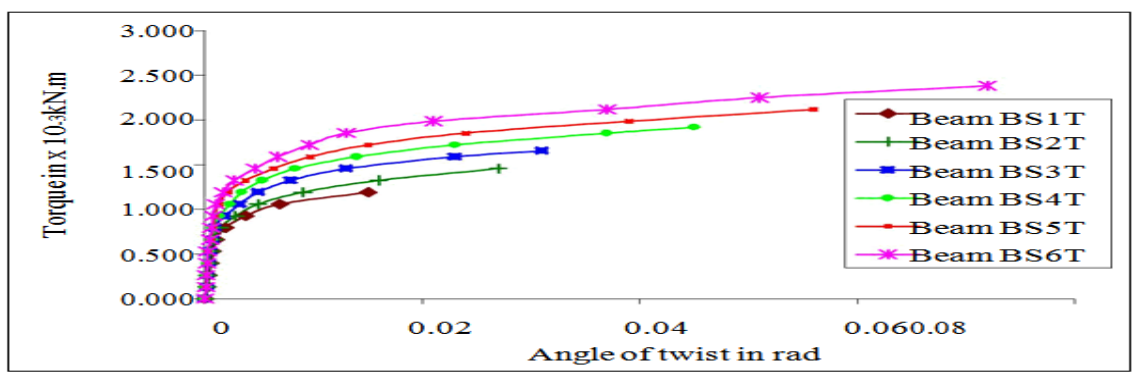

Torque versus angle of twist behaviour with reinforcement

Table. Comparisons of cracking torque and ultimate torque

\begin{tabular}{|c|c|c|c|c|}
\hline Test specimen & Type of fiber & $\begin{array}{c}\text { Volume fraction of } \\
\text { fiber }\end{array}$ & $\begin{array}{c}\text { Cracking torque } x \\
10^{-3} \mathrm{kN} . \mathrm{m}\end{array}$ & $\begin{array}{c}\text { Ultimate torque } x \\
10^{-3} \text { kN.m }\end{array}$ \\
\hline BS1T & \multirow[t]{6}{*}{ Crimpled } & $0 \%$ & $\begin{array}{l}1059 \\
\end{array}$ & 1258 \\
\hline BS2T & & $1.0 \%$ & 1324 & 1589 \\
\hline BS3T & & $0 \%$ & 1655 & 2053 \\
\hline BS4T & & $1.0 \%$ & 1854 & 2318 \\
\hline BS5T & & $0 \%$ & 2053 & 2516 \\
\hline BS6T & & $1.0 \%$ & 2318 & 2847 \\
\hline
\end{tabular}


Experimental Study on Tortional Shear Behaviour of High Strength Steel Fiber Reinforced Concrete with Varying Volume Fraction

Table. Details of average energy absorption due to torsional impact

\begin{tabular}{|c|c|c|c|c|}
\hline Test specimen & Type of fiber & $\begin{array}{c}\text { Volume fraction of } \\
\text { fiber }\end{array}$ & $\begin{array}{c}\text { Average energy } \\
\text { absorption in N.m } \\
\text { at cracking torque }\end{array}$ & $\begin{array}{c}\text { Average energy } \\
\text { absorption in N.m } \\
\text { at ultimate torque }\end{array}$ \\
\hline B1TI & \multirow[t]{4}{*}{ Straight } & $0 \%$ & 80.8 & 121.2 \\
\hline B2TI & & $0.5 \%$ & 303 & 484.8 \\
\hline B3TI & & $1.0 \%$ & 363.6 & 565.6 \\
\hline B4TI & & $1.5 \%$ & 424.2 & 626.2 \\
\hline B5TI & \multirow[t]{3}{*}{ Crimpled } & $0.5 \%$ & 343.4 & 787.8 \\
\hline B6TI & & $1.0 \%$ & 565.6 & 888.8 \\
\hline B7TI & & $1.5 \%$ & 828.2 & 1151.4 \\
\hline
\end{tabular}

The average energy absorption required at first crack of fiber reinforced concrete beams with $0.5 \%$, $1.0 \%$ and $1.5 \%$ crimpled fiber content was found to be 4.25, 7 and 10.25 times more when compared with plain concrete beam. Similarly the energy absorption required at failure of fiber reinforced concrete beam with $0.5 \%, 1.0 \%$ and $1.5 \%$ crimpled fiber content was found to be $6.5,7.3$ and 9.5 times more when compared with plain concrete beam. Histograms showing

\section{Details of Cracking Torque and Ultimate Torque}

\begin{tabular}{|c|c|c|c|}
\hline Test specimen & Volume fraction of fiber & Cracking torque $\mathbf{x} \mathbf{1 0}^{-3} \mathbf{k N} . \mathbf{m}$ & Ultimate torque $\mathbf{~ 1 0}^{-3} \mathbf{k N} . \mathbf{m}$ \\
\hline B1TC & $0 \%$ & 795 & 1059 \\
\hline B2TC & $1.0 \%$ (Crimpled) & 927 & 1258 \\
\hline B3TC & $0 \%$ & 1192 & 1589 \\
\hline B4TC & $1.0 \%$ (Crimpled) & 1324 & 1788 \\
\hline B5TC & $0 \%$ & 1589 & 2119 \\
\hline B6TC & $1.0 \%$ (Crimpled) & 1722 & 2384 \\
\hline
\end{tabular}

The cracking torque of concrete beams B2TC, B3TC, B4TC, B5TC and B6TC was found to be $17 \%$, $50 \%, 67 \%, 100 \%$ and $117 \%$ more when compared with plain concrete beam. Similarly the ultimate torque of concrete beams B2TC, B3TC, B4TC, B5TC and B6TC was found to be 19\%, 50\%, 69\%, $100 \%$ and $125 \%$ more when compared with plain concrete beam B1TC. The ultimate torque of beams B1TC, B2TC, B3TC, B4TC, B5TC and B6TC was found to be 33\%, 36\%, 33\%, 35\%, 33\% and 38\% more when compared with the cracking torque.

\section{CONCLUSION}

- Use of fiber reinforcement in concrete along with conventional shear and flexural reinforcement makes it more ductile and therefore more suitable for torsion resistant structures.

- When the theoretical and the observed values of the cracking torque and the ultimate torque are compared, it is observed that the values are within the acceptable range of variation from experimental observations in the case of all the specimens. Therefore, it may be concluded that the results obtained from these tests may be relied upon and may be used in further investigations.

- The torque at failure of fiber reinforced concrete beam with $0.5 \%, 1.0 \%$ and $1.5 \%$ straight fiber content was found to be $5 \%, 11 \%$ and $16 \%$ more when compared with plain concrete beam.

- Appreciable crack width was noticed because of torsional impact. The failure of the plain concrete beams was sudden and with low energy absorption. But in fiber reinforced concrete beams, the failure was not sudden and it took increased number of blows.

- Due to cyclic torsion initially, the cracks widened and closed as the load was applied and released. Eventually, at the failure stage the crack kept on widening and the concrete failed.

\section{REFERENCES}

[1] ACI Committee 544 (1988), 'Design Considerations for Steel Fiber Reinforced Concrete', ACI Structural Journal Proceedings, Vol. 85(5), 563-580.

[2] Alexander J.G.S. and Cheng J.J.R. (1996), 'Field application and studies of using CFRP sheets to strengthen concrete bridge girders', Proc. Advanced composite materials in bridges and structures, M. M. El-Badry, ed., Canadian Society for Civil Engineering, Montreal,465472. 
Experimental Study on Tortional Shear Behaviour of High Strength Steel Fiber Reinforced Concrete with Varying Volume Fraction

[3] Arduini M., Di Tommaso A., Manfroni O., and Nanni A. (1996), 'Failure mechanisms of concrete beams reinforced with Bridges and Structures, M.M. El-Badry, ed., Canadian Society forCivilEngineering,Montreal,25

Citation: Bolagani. bhavani, et.al. "Experimental Study on Tortional Shear Behaviour of High Strength Steel Fiber Reinforced Concrete with Varying Volume Fraction", International Journal of Constructive Research in Civil Engineering, 5(3), pp. 17-23. DOI: http://dx. doi.org/10.20431/2454-8693.0503002

Copyright: (C) 2019 Authors, This is an open-access article distributed under the terms of the Creative Commons Attribution License, which permits unrestricted use, distribution, and reproduction in any medium, provided the original author and source are credited. 